\title{
Marguerite de Navarre, CEuvres complètes: IV. Théâtre
}

\section{Michele Mastroianni}

\section{(2) OpenEdition}

\section{Journals}

\section{Edizione digitale}

URL: http://journals.openedition.org/studifrancesi/9150

DOI: 10.4000/studifrancesi.9150

ISSN: 2421-5856

\section{Editore}

Rosenberg \& Sellier

\section{Edizione cartacea}

Data di pubblicazione: 1 juin 2008

Paginazione: 172

ISSN: 0039-2944

\section{Notizia bibliografica digitale}

Michele Mastroianni, «Marguerite de Navarre, EFuvres complètes: IV. Théâtre», Studi Francesi [Online],

154 (LII | I) | 2008, online dal 30 novembre 2015, consultato il 12 janvier 2021. URL: http://

journals.openedition.org/studifrancesi/9150 ; DOI: https://doi.org/10.4000/studifrancesi.9150

Questo documento è stato generato automaticamente il 12 janvier 2021.

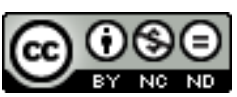

Studi Francesi è distribuita con Licenza Creative Commons Attribuzione - Non commerciale - Non opere derivate 4.0 Internazionale. 


\title{
Marguerite de Navarre, Euvres complètes: IV. Théâtre
}

\author{
Michele Mastroianni
}

\section{NOTIZIA}

MARGUERITE DE NAVARRE, Cuvres complètes: IV. Théâtre, sous la direction de Nicole CAZAURAN, édition critique établie, présentée et annotée par Geneviève HASENHOR et Olivier MILLET, Paris, Champion, 2002 («Textes de la Renaissance», 61), pp. 674.

1 Seppure in ritardo, per un contrattempo nell'invio del volume a questi «Studi», data l'alta qualità scientifica, diamo breve segnalazione dell'edizione critica di tutto il teatro di Marguerite de Navarre. I testi sono suddivisi in due gruppi: quattro Comédies bibliques, sacre rappresentazioni ispirate ai Vangeli dell'infanzia (e alla tradizione dei noëls), e sette Comédies non-bibliques, che si apparentano al genere delle moralités. Le prime, formando un corpus coerente, sono presentate in un'introduzione generale comune; le altre, molto diverse come tematica, anche se sempre strettamente connesse a spunti religiosi e morali, sono precedute singolarmente da un'introduzione. L'insieme di questi 'cappelli' rappresenta un'indagine approfondita sull'intrecciarsi di riferimenti e fonti diverse nella teologia margheritiana. Indagine completata da un'annotazione minuziosa e completa. Esemplare, sul piano filologico, l'approccio editoriale. 